University of Rhode Island

DigitalCommons@URI

The Rhode Island Current Conditions Index

Economics

3-2004

\title{
Rhode Island Current Conditions Index - March 2004
}

Leonard Lardaro

University of Rhode Island, lardaro@uri.edu

Follow this and additional works at: https://digitalcommons.uri.edu/ricci

Part of the Econometrics Commons

Terms of Use

All rights reserved under copyright.

\section{Recommended Citation}

Lardaro, Leonard, "Rhode Island Current Conditions Index -- March 2004" (2004). The Rhode Island Current Conditions Index. Paper 134.

https://digitalcommons.uri.edu/ricci/134

This Article is brought to you for free and open access by the Economics at DigitalCommons@URI. It has been accepted for inclusion in The Rhode Island Current Conditions Index by an authorized administrator of DigitalCommons@URI.For more information, please contact digitalcommons-group@uri.edu. 


\section{Current Conditions I ndex \\ LEONARD LARDARO URI}

Also available online: http:/ / members.cox.net/ lardaro/ current.htm

Volume X, Number 6

March 2004

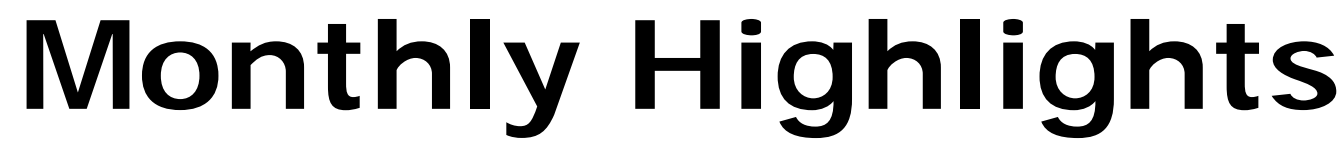

Rhode Island ended the first quarter on a curious note - the Current Conditions Index fell from its multi-year high of 92 in February to 58 in March, as only seven of twelve indicators improved. While this might appear to indicate a threat to this recovery, note that the $\mathrm{CCl}$ for the first quarter of 2004 averaged 75, almost double the average of last year's first quarter, 42. The $\mathrm{CCl}$ 's decline from February to March reflects the fact that the recent acceleration in activity that we have witnessed was not sustainable. The lower $\mathrm{CCl}$ in March thus reflects our "shifting gears" to a more sustainable pace.

Examination of individual indicator performances in March shows that a great deal of strength remains. Retail sales momentum continued, fueled by consumer sentiment, and housing growth remained strong. However, even though layoffs continued to slow, unemployed persons are still experiencing difficulty finding employment.

Retail Sales grew strongly once again in March $(+11.0 \%)$, fueled by strongly improving US Consumer Sentiment $(+23.3 \%)$. Volatility in new home construction also continued in March, as Single-Unit Permits surged again, this time by

\section{Indicators - \% Change}

Government Employment

$0.5 \mathbf{Y}$

US Consumer Sentiment

$23.3 \mathbf{Y}$

Single-Unit Permits

$17.4 \mathbf{Y}$

Retail Sales

Help Wanted Advertising

Priv. Serv-Prod Employment

$11.0 \mathbf{Y}$

$-6.1$

$1.4 \mathrm{Y}$

Man-Hours Manufacturing

$-2.0$

Manufacturing Wage

Labor Force

$1.3 \mathrm{Y}$

Benefit Exhaustions

$-0.8$

0.8

New Claims

$-1.0 \mathrm{Y}$

Unemployment Rate

1.8

\section{Y = I mproved Value}

an amazing 17.4 percent compared to last March. Single-Unit Permits have now grown at double-digit rates for six of the last seven months, while Retail Sales have attained doubledigit growth for every month this year.

While national payroll employment has begun to surge, Rhode Island has not shared that good fortune. In March, Rhode Island's payroll employment actually fell (by 800) from February's level. Compared to its level one year ago, however, payroll employment here rose by 6,300 . As this was occurring, Private Service-Producing Employment growth has begun to decelerate, growing at a 1.4 percent rate in March, well below the growth rates for the prior two months. But, despite ongoing budget difficulties, Government Employment rose once again in March $(+0.5 \%)$.

Rhode Island's manufacturing labor market weakened a bit in March. Manufacturing Man-hours fell by 2 percent after rising slightly in February $(+0.8 \%)$. March's decline was the most rapid since October of 2003. Growth in Rhode Island's Manufacturing Wage slowed to 1.3 percent after accelerating the prior two months. Incredibly, Rhode Island's average Manufacturing Wage remains below $\$ 13$ per hour, a value comparable to the US average almost 10 years ago!

Long-term unemployment, as reflected in Benefit Exhaustions, worsened by 0.8 percent in March, its first rise since October of 2003. Along with this, Rhode Island's Labor Force fell by 0.8 percent, and its Unemployment Rate rose. The only good news on the labor demand front was a decline in layoffs (New Claims).

March's $\mathrm{CCl}$ performance points to the possibility that as the pace of national economic activity has now begun to accelerate, Rhode Island may well be returning to its traditional role - as a lagging economy. Let's hope this is not the case, in spite of what we know about how problematic our cost and tax structures are.

\section{Current Conditions I ndex}

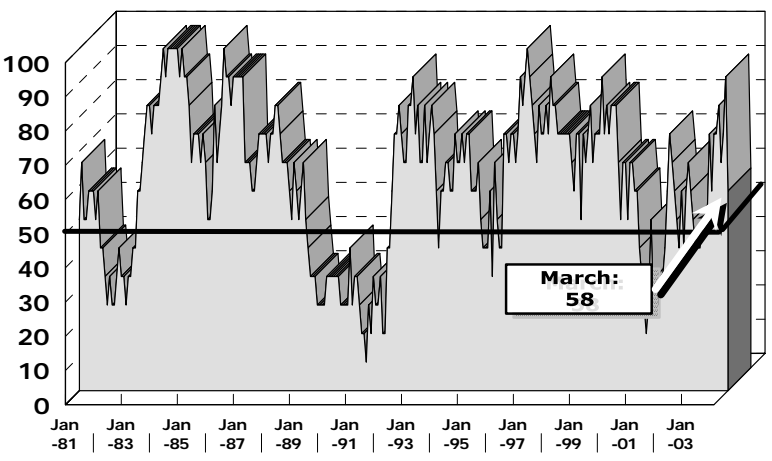

\begin{tabular}{|c|c|c|c|c|c|c|c|c|c|c|c|c|}
\hline & J an & Feb & Mar & Apr & May & J un & J ul & Aug & Sep & Oct & Nov & Dec \\
\hline 2003 & 42 & 42 & 42 & 50 & 50 & 50 & 75 & 58 & 75 & 75 & 83 & 67 \\
\hline 2004 & 75 & 92 & 58 & & & & & & & & & \\
\hline
\end{tabular}

